\title{
Tax Planning and its Legally Hazardous Instruments
}

\author{
Bianca Cristina Ciocanea \\ sb19biu@gmail.com \\ Ioan Cosmin Pitu \\ cosmin pitu@yahoo.com \\ Mihaela Paraschiva Luca \\ mihaluca2006@yahoo.com \\ Lucian Blaga University of Sibiu, Romania
}

\begin{abstract}
Taxpayers often look for means to cut as much as possible on the amount of taxes they owe the state as a result of their business activity. Whether they choose legally hazardous variants, or they choose not to declare the entire economic operations performed, whether they speculate on the loopholes of the often-imperfect legislation, diminishing tax-payment to the state budget is the main desire of economic agents and they generally do this by three defining methods, namely: tax planning, tax evasion, tax fraud. The article discusses also the measures to be taken by the EU to combat illegal practices and minimize the impossible-to-erradicate tax evasion phenomenon.
\end{abstract}

Key words: tax planning, tax evasion, tax haven, off-shore area, transfer pricing

JEL classification: H21, H26, E62.

\section{Introduction}

The art of tax planning is each taxpayer's ability to use means, methods and legal ways to reduce tax liability and this is one of the most important components of the financial management of an entity.

Reducing tax-payment can be done in three ways, namely:

Tax planning, whose objective is not necessarily to reduce tax payment to the minimum, but the cost in general, is an element of economic planning.

Tax evasion consists in transactions which differ from normal business activities and seem artificial being meant to exploit advantages in matters of taxation and they set themselves against law. The taxpayer seeks to avoid tax liability, tax laws being interpreted in an abnormal way.

Tax fraud represents the total illegal actions that a taxpayer undertakes in order to avoid paying taxes when certain facts giving rise to tax liabilities have already taken place. In the case of tax evasion, false information is provided, and the consequences are accordingly, consisting of administrative and criminal sanctions. In this case tax may be based on estimates.

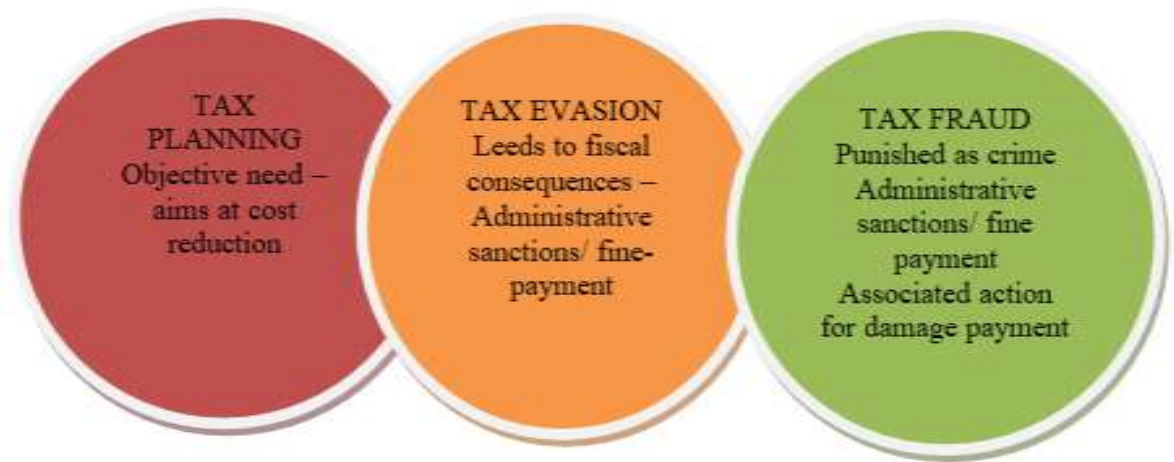

Fig. 1. Tax planning vs tax evasion vs tax fraud Source: author 
Tax planning has emerged as an objective need in business, driven by tax legislation itself which provides different tax regimes, a legal framework that allows for calculation methods of the tax base and leeds to certain tax concessions.

Tax planning is subject to the state's interest in providing tax incentives to encourage the production process of certain categories of economic operators, being meant for social and economic development. Taxpayers' desire to reduce the tax burden and to increase their own resources, necessary for the proper course of business, and the requirements of market competition determine the objective nature of tax planning.

Tax planning is based on international treaties and agreements concluded between countries.

Tax planning stages depend on the subject of planning - taxes resulted from specific transactions or the business as a whole entity. Therefore, both stages and the instruments chosen to be used in tax planning are carefully selected by the taxpayer, primarily depending on the type of activity, in order to be as efficient and as difficult to control by the competent authorities.

The extensive variety of tax planning instruments allows the economic operator to legally minimize tax liability, refraining from committing intentional tax crime and avoiding serious mistakes in the development of personal methods of tax liability minimization.

To have an overview of the tax planning legal application and its hazards beyond legality, the figure below shows each possible action the taxpayer takes in the tax planning scheme:

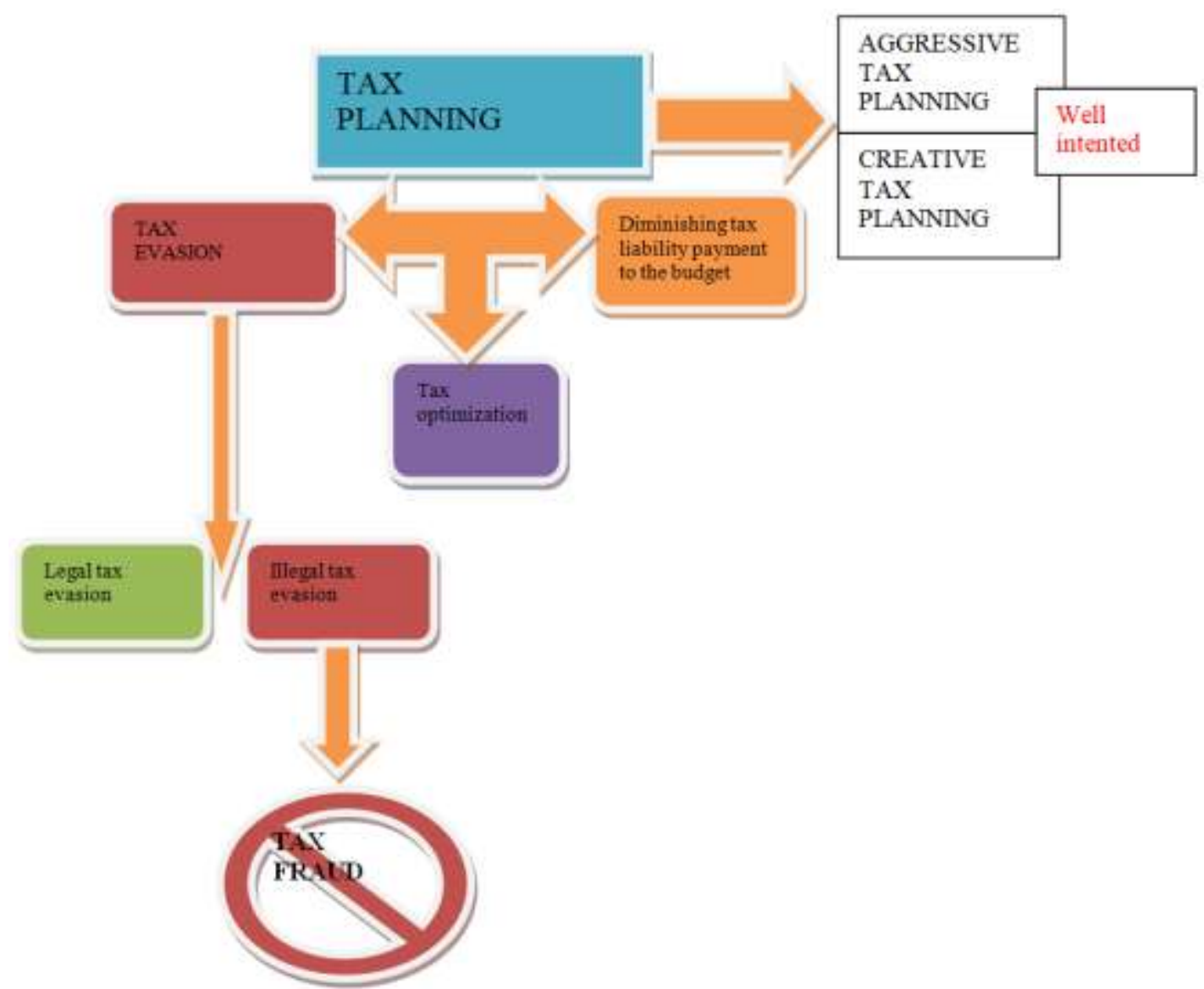

Fig. 2. Legally hazardous tax planning

Source: author

Concluding the display in the chart above, taxpayers, honest or not, pursue by any means diminishing tax liability payment to the state budget, adopting either legal methods, choosing to act within legal limits or planning their actions so that they be as little subject to taxation, or, even more, passing to the most undesirable extreme, that of tax evasion or tax fraud. 


\section{Most Used Tax Planning Instruments 2.1 Transfer Pricing}

Managers of economic entities may use various activities to reduce taxes artificially by transferring the tax burden, tax-generating, through business transactions, with other companies in their group / owned by them, by practising a series of preferential prices.

Tax authorities seek to determine and tax the adequate value corresponding to profits based on the "arm's length principle" in order to protect the tax base thus obtained in the area of responsibility. According to the arm's-length principle, the intra-group prices are equivalent to prices applied per each type of transaction, where economic entities acted independently on the market, and that, if they were not affiliated parties.

The arm's length principle involves the application of different methods in different circumstances. These methods compare the prices of affiliated party transactions with results from similar transactions conducted between independent parties. In many countries, including Romania, there is specific legislation requiring the contents of the file containing transfer pricing. Lack of documentation relating to such transactions that would show their respecting of the arm's length principle, determine the tax authorities to apply fiscal sanctions of adjusting the exercised prices between affiliated parties.

The concept of affiliation is defined in Law 227/2015 regarding the Fiscal Code and intervenes in situations where a legal entity owns, directly or indirectly, including holdings of affiliated persons, at least $25 \%$ of the value/number of shares or voting rights in the other legal entity or if it is effectively in control of that other legal entity.

Similarly, the Fiscal Code defines the affiliation relationship in situations when an individual is affiliated with another individual, if they are husband/wife or up to III $^{\text {rd }}$ degree relatives included, or an individual is affiliated with a legal entity if the individual holds, directly or indirectly, including holdings of affiliated persons, at least $25 \%$ of the value/number of shares or voting rights within a legal entity or if he is effectively in control of that legal entity.

It is believed that an individual is effectively in control of a legal entity if it is established that, both factually and legally, by using information and/or documents, the administrator/the board of directors:

-has/have the ability to decide on the activity of the legal entity concerned by concluding transactions with other legal entities in control by the same administrator/board of directors or

-as the leader of the legal entity, he is a shareholder or administrator within the legal entity concerned.

Transactions between affiliated parties are to be performed according to the arm's length principle. Within a transaction, or a group of transactions between affiliated parties, tax authorities can:

- adjust, if the arm's length principle is not respected,

- estimate - if the taxpayer does not provide to the relevant tax authority data required to determine whether transfer pricing, exercised within the situation analized, prevails the arm's length principle - the amount of revenue or expense related to the financial performance of any of the affiliated parties based on the level of the main market trend.

The adjustment/estimation procedure and the method of determining the level of the main market trend, as well as the situations in which the tax authority may consider that a taxpayer has not provided the information required to establish the principle observance for the analyzed transactions, are established by the Fiscal Procedure Code.

Between affiliated parties, the price for the transfer of tangible or intangible assets, or for provided services, is the transfer price.

Allocation of profits between member companies of the group, based on the functions performed by each entity and the risks assumed, is achieved via prices set for inter-company transactions. These prices are called generically "transfer pricing". 
For successful tax planning, the rule to be followed is that risks are allocated according to functions performed, and profit allocation should be made based on the functions performed and risks assumed. According to the OECD Guidelines "in transactions between two independent companies, remuneration reflects the functions that each company performs (taking into account assets used and risks assumed)" (PKF Finconta Transfer pricing - tax planning instrument).

Analysis of transfer pricing has become a need in the performing of successful tax planning. Beyond the legal obligation of drawing, at a certain given moment, the file with transfer pricing, for effective planning, both economic and fiscal, two stages of analysis are absolutely necessary, namely: functional analysis and economic analysis.

Thus, once control is increased by the tax authorities worldwide, transfer pricing has become a fiscal problem increasingly important for multinational corporations. Because of the tax authority's interpretation, independent of the arm's-length principle, multinational companies have started to pay increased attention to the transfer pricing management strategy globally.

Given that the company management uses transactions within the group of companies it controls, as a method of tax planning/optimization regarding transfer pricing policies to increase revenue and reduce risks globally, transfer pricing is no longer just a tax problem, but has become a strategic business instrument.

According to the PKF Finconta study performed in 2018 regarding Transfer Pricing in Romania by using the method: CAWI (Computer Assisted Web Interviewing), the manner of implementation, according to the group policy, regarding transfer pricing, at the level of Romanian companies, is performed as follows:

Grid legend: Transfer pricing manner of implementation according to group policy:

- light blue: $35 \%$ - it is adjusted according to regulations in Romania

- terra: $32 \%$ - there is no policy regarding transfer pricing

- grey: $18 \%$ - it is adopted without amendments at the level of a company in Romania

- yellow: 5\% - the local policy is drawn and implemented according to Romanian regulations

- dark blue: $10 \%$ - don't know

Modul de implementare a politicii grupului privind preturile de transfer

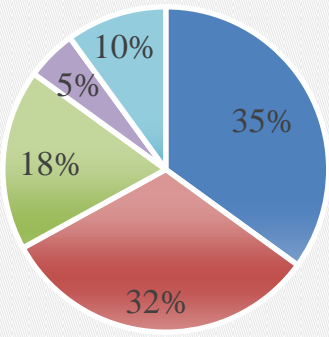

$$
\begin{aligned}
& \text { - Este ajustata conform regulilor din Romania } \\
& \text { - Nu exista o politica privind preturile de } \\
& \text { transfer } \\
& \text { - Este adoptata fara modificari la nivelul } \\
& \text { companiei din Romania } \\
& \text { - Politica locala este elaborata si implementata } \\
& \text { conform regulilor din Romania }
\end{aligned}
$$

Fig. 3 Transfer pricing manner of implementation according to group policy Source: Personal processing based on data provided by the PKF Finconta study on Transfer Pricing in Romania, 2018

As can be seen from the chart above, in $35 \%$ of companies surveyed, the policy on transfer pricing is adjusted according to the rules of Romania, in $32 \%$ of cases there is no policy on transfer pricing or in 18\% of cases, the group policy is adopted without amendments at the level of a company in Romania. It is to be noted that the questionnaire drawn up by the producer of the study received 175 answers (respondents being 49\% economic and financial executives, $16 \%$ CEOs and members of the Board of Directors, $35 \%$ other managerial roles).

In conclusion, companies should identify the main areas of risk they are exposed to, according to the specific activity carried out and adjust their transfer pricing policies in order to 
reduce economic risk and related tax risk. Such an approach could lead to the transformation of transfer pricing from a fiscal problem into a business opportunity.

\subsection{The Tax Havens and Off-Shore Areas}

Tax evasion is manifested not only nationally, but is also growing internationally. The factors that determine the extent of this scourge even beyond state borders are extremely varied. Each state has a special tax system and level of taxation different from that of other countries, so that international economic cooperation and development of relations between countries has led to the expansion of tax evasion phenomenon.

Tax evasion worldwide is facilitated by the existence of certain "tax oasis" or "tax havens" that are a benefit to those looking for a more favorable tax treatment. Tax havens are legal entities granting tax benefits to companies that establish their headquarters, or individuals, residing in their territory.

According to the OECD, the aggessive planning and optimization practices, hitting in the tax system, disturb trade and investment, eroding national tax bases and weakening the legitimacy and structure of the national tax system. It is estimated that only developing countries annually lose $\$ 50$ billion because of tax evasion through tax havens. Tax haven is the preferred tool for achieving fraud and tax evasion, and for tax planning, at international level.

Tax haven facilities and tax regimes offer preferential treatment to non-resident individuals and companies, lead the tax rate applied to income / profit from movable assets underneath tax levels in other countries and represent an opportunity for them, but have a major impact on the world economy at all its levels.

One way to optimize taxation is the establishment of offshore or onshore centers, these benefiting from a favorable tax climate. Offshore companies are companies incorporated in jurisdictions with a different taxation, depending on where the economic activity takes place. In most jurisdictions, individual taxation or the dividend tax is zero.

The offshore company is the most used tool in doing business in the tax haven. The term "offshore" means "beyond the shore" in plain language. In specialist economic language, the term encompasses all economic activities of companies beyond the national borders of the State in which they reside.

An offshore company is an entity registered in a country, or a territory, dependent on a country, with independent legislation, but no economic activities in that territory. The company does not make a profit in the country it was registered, but outside that State. States classified as tax havens offer offshore companies a generous tax status compared to companies operating within. These indulgent regulations are characterized by a reduced or non-existent taxation. The offshore company is a financial instrument used for planning and avoidance of taxes, for the increase of business profitability, for the participation (as a shareholder or partner) in business management, with full freedom of moving financial resources and indulging the owner to remain anonymous (Buziernescu, 2007). These facilities are offered by several states whose list was published in November 2018 by Eurostat. The list of these offshore financial centers include: Andorra, Antigua and Barbuda, Anguilla, Aruba, Barbados, Bahrain, Bermuda, Bahamas, Belize, Cook Islands, Curaçao, Cayman Islands, Dominica, Grenada, Guernsey, Gibraltar, Hong Kong, Isle of Man, Jersey, St Kitts and Nevis, Lebanon, Saint Lucia, Liechtenstein, Liberia, Marshall Islands, Montserrat, Mauritius, Nauru, Niue, Panama, Philippines, Seychelles, Singapore, Sint Maarten, Turks and Caicos Islands, Saint Vincent and the Grenadines, Virgin Islands (British) Virgin Islands (US), Vanuatu, Samoa (Source - Balance of Payments Vademecum, Appendix 7).

The key areas of activity in which offshore companies operate are: banking, insurance, trade (export-import), management, investment coordination, construction and assembly, recruitment, Treasury Services (Buziernescu 2007).

The tax advantages enjoyed by offshore companies registered in tax havens are divided into two distinct categories:

- advantages / direct tax benefits; 
- additional benefits beyond the favorable tax status;

Thus, tax havens may be classified according to various criteria. The most important criterion that makes them special is their importance, they are divided into primary and secondary. The primary tax havens are classified as follows:

- countries where taxation on income and capital-increases (or so-called "zero havens") does not apply and for natural persons there is no taxation: The Bahamas, Bahrain, Bermuda, Cayman Islands, Nauru Saint-Vincent, Turks and Caicos, Vanuatu and Monaco. For example, see the charts below showing two of the countries, Bahamas and Vanuatu, where the individual tax is zero.
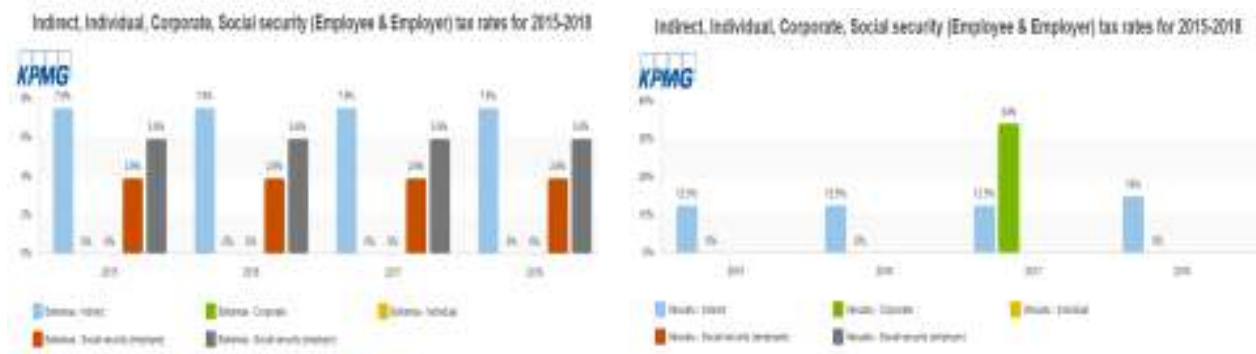

Fig. 4. The evolution of tax rates in THE BAHAMAS and VANUATU, 2015-2018individual tax $0 \%$

Source: the author's processing based on KPMG data

- states where taxpayers receive relief on obtained benefits through the use of outside the country operations and income/benefit taxation is established on a territorial basis: Costa Rica, the territory of Hong Kong, Liberia, Malaysia, Panama, the Philippines, Venezuela.

- countries where tax rates are low due to tax agreements on double taxation: Liechtenstein, Switzerland, British Virgin Islands, the Netherlands Antilles, Jersey, Guernsey, Isle of Man, Ireland. companies;

- states, Singapore included, that offer specific benefits to holdings or offshore

- countries that offer tax exemptions to industries created to develop export: Ireland, for companies created before January 1, 1981;

- countries which offer specific advantages to certain companies: Antigua, Anguilla, Grenada, Jamaica, Barbados.

Secondary tax havens include small countries like the Vatican, Maltese Republic, French Polynesia, Tonga Islands, Haiti, Virgin Islands, these representing small areas with a small population. These states neither apply any taxation, nor impose certain income earned by individuals or companies, or they either grant tax exemptions to the activities of certain companies or set odds greatly reduced.

Secondary tax havens are characterized by the fact that the level of certain forms of income taxation is high, but there are certain particular provisions, which can be used by investors in tax planning operations. One of the most important facilities for a company is that it is free to open accounts in any currency to any foreign banks in order to send and receive payments in any currency without restrictions. Also, there are no restrictions on capital export.

The option of doing business through tax oases is determined by fiscal motivations, often legally hazardous, grouping in:

- tranzactions within the spirit and letter of the law, framed as tax planning operations. Companies incorporated inside tax havens tend to maximize profits by minimizing tax obligations by any legal means. The practice is common in multinational companies based in tax haven centers who control the entire business or they direct their profits to the parent company, which is a tax planning technique. Moving profits to tax havens, from countries which they are made in, is done in various ways such as: the provision of services by companies registered in tax havens to its subsidiaries registered in different countries where taxation is high, 
the export of goods with prices below the real ones in the country with high taxation to the company registered in the fiscal haven, the goods being then resold at market price, thus making a higher profit which is not taxed.

- tax avoidance situations, this being the case with transactions that speculate legislative interests. Examples are the use of investment companies, some forms of services and constructions performed via entities such as tax havens, etc.

- fraudulent transactions, which lead to tax evasion. This category includes activities evading taxes by declaring some operations of trading goods - apparently causing loss in the country business performance - through a tax haven in order to conceal reality, transactions which, in fact, do not occur.

Outsourcing in the same country or region is called onshore outsourcing, a growing number of companies heading towards practicing it. Advantages of cultural and linguistic nature are major motivations for this choice, and at relatively low costs. In this context, communication between client and supplier is much easier and trade relations take place more easily, travel expenses being also removed.

\subsection{The Territorial Jurisdiction Method}

Choosing where to set up a company or its business activity can influence taxation by the fact that some states, regions and legal areas grant legal tax incentives. In Romania, there are special areas categorized as disadvantaged as well as free economic zones. The disadvantaged areas policy represents a distinctive regional development policy, being determined by the existence of factors that classify them as disadvantaged areas in certain respects (socio-economic, structural, geographic location, etc.). Tax incentives for investors in these areas consist of exemption from corporate tax, long term customs and VAT tax relief etc. The legal framework regulating these facilities is the Government Emergency Ordinance (GEO=OUG) no.24 / 1998 on disadvantaged areas, republished, with further amendments.

\subsection{An Entity's Legal Form of Organization}

Choosing an entity's legal form of organization has influences on the manner of taxation, both in the case of income tax and in the case of tax owed for employees, the management of economic entities being thus able to influence the tax level owed to the state budget.

In Romania, the most common forms of legal organization of an economic entity are: Natural Person (Freelancer/Self-employed=PFA), Individual Entrepreneur (II), Limited Liability Company (SRL) and Start-up Limited Liability Company (SRL-D). The Romanian taxation system varies according to the legal form an entity has, from SRL to SRL-D (the latter being indulged certain tax incentives on a limited period, the most important being the Social Security Tax exemption for not more than four employees). Similarly, choosing a legal form such as PFA, II or a Family Enterprise (IF) is another alternative to paying tax on small enterprise revenue (1 or 3\% applied to turnover). Natural Persons, Individual Entrepreneurs or Family Enterprises may choose taxation based on the actual income system (16\% taxation on net revenue resulted from gross income collection minus total deductible payment); the other taxation method is based on regulated income $(10 \%$ taxation on normed income established by the fiscal authority in each Romanian county according to activity field).

Romanian legislation clearly defines the forms of legal organization of an entity, thus PFA (Natural Person/Freelancer), II (Individual Entrepreneur) and IF (Family Enterprise) are regulated by GEO 44/April 16, 2008 on economic activity performed by PFAs, IIs, and IFs, with subsequent amendments and SRLs and SRL-Ds are regulated by Law 31/1990, the law of companies, republished, with its subsequent amendments and completions, together with GEO 6/2011 on stimulating the start-up entrepreneurs to set-up and develop micro-enterprises.

The 2018/2019 Fiscal Code is drawn to the advantage of economic entities' independent form of organization, more than the $2016 / 2017$ one, due to taxation limited by the minimum gross salary, and payment liability emerges only if the estimated net income/ obtained net income 
exceeds 12 minimum gross salaries. A micro-enterprise having employees is a business form of organization mostly disadvantageous in 2019 , too. The level of taxation exceeds $26 \%$ applied to net income. Up to the amount of 24.960 lei annual net incomes (the calculus base in the case of Social and Health Security Contributions=CASS includes several types of income), there is no liability to pay social contributions, only the $10 \%$ tax applied to the obtained net income.

In the period between 2015-2018 major legislative changes were produced in the tax treatment of Romanian company earnings. The annual income upper-limit allowing an enterprise to be included in the micro category was increased over 15 times, increasing from EUR 65,000 in 2015 to EUR 1,000,000 in 2018, according to a Fiscal Council report. Concerning tax rates applied to microenterprise revenues, they have been cut and divided by the number of employees since 2016. Thus, the further upper-limit increase of the micro-enterprise income in 2018 results in the significant weight increase on income taxation vs corporate taxation.

This transition, from corporate taxation to taxation on taxpayers' income, occurrs in a period of economic expansion when company profitability is high, boosting revenue loss for the state budget.

Similarly, allowing companies to opt for corporate tax or income tax enables them to optimize their tax obligations, with further negative consequences on the budget revenues.

\subsection{The Tax and Accounting Policy Method}

The accounting policies may affect the tax application to many transactions being able to be used as a tax planning instrument. The Fiscal Code, in some cases, makes reference to the accounting policy accepting asset valuation methods of financial accounting. Thus, for tax purposes, there may be used financial accounting methods based on the provisions of the National Accounting Standards and IFRS, which do not contravene to the Fiscal Code provisions. The method procedures of goods and materials stock recording (FIFO, LIFO, weighted average cost), in financial accounting, are accepted for tax purposes and may influence the extent of the entity's financial performance. Also, the entity's financial performance may be influenced by the depreciation of fixed assets held in the company's patrimony (linear depreciation, accelerated, digressive) being thus, from a management point of view, a form of tax planning.

\section{EU Fighting Measures against Tax Evasion and Aggressive Tax Planning}

Owing to the fact that tax evasion and tax fraud are negative phenomena, manifesting both within the borders and beyond the borders of the EU Member States, and even outside EU, urgent and effective action is needed internationally, the efforts of one state not being enough to lead an effective fight against this phenomenon.

Tax laws of a country should not be so lenient so that tax circumvention is facilitated in another Member State. Given the nature of cross-border tax evasion and fraud, firm action at EU level is essential.

In recent years, given the EU's establishing of some regulations, we have made significant progress. The EU has developed or is about to further develop legislative initiatives to which Member States must align, regulations on information exchange between the EU countries and a rapid response mechanism for combating VAT fraud.

The EU pays special attention also to the equitable taxation of enterprises. The legislative breaches existing in the case of tax systems allow enterprises to adopt models of "aggressive tax planning" to minimize tax liabilities. Thus, a better cooperation between states and information exchange between tax administrations will slow down these practices.

EU member governments have a duty to verify whether tax regimes applied to enterprises are transparent and fair. Allthesame, laws applicable to enterprises must be designed so as not to unfairly attract companies to the detriment of other EU member states, or to erode the tax base applicable in other states. For this purpose, a code of conduct has been signed - 
adopted by the ECOFIN (Council of Economics and Finance Ministers) in December 1997 according to which governments undertake not to address such practices.

Good fiscal governance is one among the means of combating fraud and tax evasion being considered a milestone in the recent measures adopted by the EU Commission and ultimately at an international level. The basic motivation is that the phenomenon is spreading across the borders of EU countries.

Tax evasion is a conscious action of the taxpayer in breach of a legal provision in order to avoid paying due tax liability, a reason for which the authorities approach the subject by laying an emphasis on good fiscal governance.

The concept of good fiscal governance is increasingly being debated by European and international institutions, minimum standards of good fiscal governance being developed, materialized in initiatives and debates to identify the best legislative approach to combat the tax evasion phenomenon.

The European Union must assume a leading role in promoting good fiscal governance and, in particular, in the automatic exchange of information worldwide.

Thus, in 2013, we have created new international structures: Eurofisc and The Good Fiscal Governance, Aggressive Tax Planning and Double Taxation Platform. In order to improve good governance in the tax area, EU Member States must promote a series of actions meant to mitigate and combat tax evasion and aggressive tax planning.

In this respect, early in 2016, in its actions to promote good tax governance, the EU has developed a set of measures to combat tax evasion, measures that are part of the EU Commission programme for a more balanced taxation on company revenues, simpler, more transparent and effective within the Union. The package includes factual measures to combat aggressive tax planning, improve fiscal transparency and establish a fair tax competition for all companies in the European Union. The EU considered that this package will help Member States to act firmly against tax evasion and aggressive tax planning. The Council Directive is one of these measures establishing regulations against practices that avoid tax liabilities which directly affect the functioning of the internal market COM / 2016/026 final - 2016/011 (CNS).

The EU Directive establishing regulations against practices to avoid tax liabilities had as its starting point the conclusion of the European Council of December 18, 2014 which emphasized "the urgent need to intensify efforts to combat tax evasion and aggressive tax planning both globally and within the Union". The Directive sets minimum common regulations against this practice of avoiding tax liability having direct and immediate repercussions on the internal market, respectively measures to combat the tax base erosion and the transfer of profits as agreed by the Organization for Economic Cooperation and Development (OECD).

Through the new regulations, the EU Directive stands for measures regulating directly the functioning of the internal market, the Directive coming into force on January 1, 2019. The measures that each Member State is to implement and ensure their transposition into national legislation regulate on the fight against some common forms of aggressive tax planning concerning:

$>$ Deduction of interest;

$>$ Exit tax;

$>$ A turn from tax exemption to granting credits, the so-called switch-over amendment;

$>$ The anti-fraud general regulation;

$>$ The regulation on controlled foreign corporations (CFCs);

$>$ A framework for the fight against the non-uniform treatment of hybrid elements;

Because these regulations must fit in the 27 various national systems of taxation, a general framework is provided, each state being able to define specific regulatory elements independently, according to the tax system, the norm implementation being a follow-up meaning to strengthen a medium level of protection against aggressive tax planning in the internal market. 
Even that the implementation term of the regulations provided by the EU Directive no. 1164/2016 was established for January 1, 2019, (respectively, December 31, 2019, with implementation beginning January 2020 regarding the provisions on exit tax), Romania has chosen to implement some of these regulations even starting January 1, 2018, proceeding to amending the Fiscal Code via GEO no. 79/2017 amending and completing Law no.227/2015. Within this framework:

- It has established the limited deduction of expenses within the $10 \%$ interest limit from the calculus base, when exceeding the upper-limit of 200,000 EUR;

- The difference between the market value and the fiscal value of assets transferred is taxed at $16 \%$ if a taxpayer is transferred to another state (exit tax);

- The anti-fraud general regulation is applicable to situations deemed less honest, performed in order to obtain tax advantage;

- In Romania, CFCs will include in the tax base passive income they did not distribute in proportion to the $\mathrm{CFC}$ shareholding;

\section{Conclusions}

Nowadays, when aggressive tax planning has major repercussions on the economies of Member States and the European Union budget, it is necessary that EU should take a leading role in promoting good tax governance and, in particular, the automatic exchange of information worldwide.

The EU pays special attention to fair taxation of enterprises. Legislation loopholes within tax systems allow enterprises to adopt models of "aggressive tax planning" to pay lower taxes. Thus, a better coordination between states and exchange of information between tax administrations will slow down these practices.

The European Commission leads the international efforts to combat fraud and tax evasion contributing to ensuring the transformation of the information automatic exchange into the new global standard in the field, based on well-defined rules of the Union.

We consider necessary to maintain the EU's sustained rithm in providing technical assistance to emerging economies in order to respect the principle of good governance.

Similarly, the development of new international regulations taking into account current EU mechanisms for the automatic exchange of information should be a priority goal for the competent bodies in making decisions and drawing EU legislation.

EU should strengthen its position in G20 discussions (Group of Twenty finance ministers and the central bank governors) in relation to the tax base erosion and the transfer of profits, in accordance with the advice given in the European Council conclusions and based on developments within the EU in tackling tax havens and aggressive tax planning.

\section{References}

1. Buziernescu, R., Paradisurile fiscale international (Tax Havens Internationally), Finante-provocarile viitorului (Finances - Future Challenges), Year VI, No. 6/2007 pg.178-189;

2. Graur, A., Planificarea fiscala instrument de optimizare a datoriilor fata de buget (Fiscal Planning, an Optimization Instrument in Tax Payment to the Budget), Revista / Journal „ECONOMICA” (THE ECONOMIC Review/Journal) no.1 (99) 2017;

3. Saguna D.D., Radu D.I., Paradisurile fiscale - implicatii economico-juridice (Tax Havens - Economic and Legal Implications), C.H. Beck Publishing House;

4. Voicu, C., Criminalitatea afacerilor (Business Criminality), Ministerul de Interne Publishing House, 1997, p. 27;

5. Criclivaia, D., Optimizarea fiscală și posibilități de aplicare a acesteia in practica fiscală autohtonă, (Tax Optimization and Application Possibilities in the Inland Tax Practice), Revista economica - Seria Stiinte exacte si economie (The Economic Review - the Series Exact Sciences and Economy);

6. Manual de instruire privind combaterea spalarii banilor si a finantarii terorismului (A Handbook on the Fight against Money Laundry and Terrorism Funding); 
7. Directiva (UE) 2016/1164 a Consiliului din 12 iulie 2016 de stabilire a normelor impotriva practicilor de evitare a obligațiilor fiscale care au incidență directă asupra funcționării pieței interne (The EU Directive 1164/2016 of the European Council of July 12, 2016 drawing regulations against the practice of tax liability avoidance directly affecting the internal market);

8. Legea nr. 227 din 2015 privind Codul Fiscal (Law no. 227/2015 on The Fiscal Code);

9. O.P.A.N.A.F. nr. 222/2008 - conținutul dosarului prețurilor de transfer (National Fiscal Administration Order no. 222/2008 - on the content of the file regarding transfer pricing)

10. O.P.A.N.A.F. nr. 442/2016 - privind cuantumul tranz̧acţiilor, termenele pentru intocmire, continutul și condițiile de solicitare a dosarului prețurilor de transfer și procedura de ajustare/estimare a prețurilor de transfer (National Fiscal Administration Order no. 442/2016 - on transaction amounts, draw-up due terms, content and request conditions of the transfer pricing file and the adjustment/estimation procedure of transfer pricing);

11. www.pkffinconta.ro, PKF Finconta: Suport de curs - Preturile de transfer - instrument al planificarii fiscale; A Course on Transfer Pricing - Tax Planning Instrument;

12. Legea 30/2019 pentru aprobarea Ordonanței de urgență a Guvernului nr. 25/2018 privind modificarea și completarea unor acte normative,precum şi pentru aprobarea unor măsuri fiscal-bugetare (Law 30/2019 on approving the GEO no. 25/2018 providing the amendment and completion of some regulations, as well as approving some fiscal-budgetary provisions);

13. bttps:// europa.eu/european-union/topics/taxation_ro accesed 10.02.2019

14. bttps:/ / eur-lex.europa.eu/legal-content/RO/TXT/?uri=CELEX\%3A32016L1164 accesed 06.02.2019

15. bttp:/ / wmw.pkeffinconta.ro

16. https:/ / wnw.startupcafe.ro/ taxe/ impozit-bitcoin-ethereum-monede-virtuale-2019.htm accesat 06.02.2019

17. http:// ec.europa.eu/eurostat/statisticsexplained/ - 19/11/2018 accesed 03.02.2019

18. bttps:// wnw.startupcafe.ro/taxe/ impozit-venit-profit-firma-evolutie-taxe-microintreprindere.btm accesat 06.02.2019

19. https:// wnw.researchgate.net/publication/273457105_Optimizarea_fiscala_si_posibilitati_de_aplicare_a _acesteia_in_practica_fiscala_autobtona accesed 06.02.2019

20. bttp:/ / www.outsourcingportal.eu/ro/nearshore-offshore-sau-onshore-care-este-alegerea-potrivita accesed 09.02.2019 